\title{
The Rate of Aging of the Dunaliella viridis Teodor. Culture Depends on the Algae Pre-Adaptation to Copper Sulfate Toxic Effect
}

\author{
A. I. Bozhkov*, M. K. Kovaleva, N. G. Menzyanova, Y. A. Kuznetsova \\ Research Institute of Biology, V.N. Karazin Kharkov National University, 4, Svobody Sq., Kharkov, Ukraine \\ Email: bozhkov@univer.kharkov.ua
}

Received 12 April 2014; revised 16 May 2014; accepted 27 May 2014

Copyright (C) 2014 by authors and Scientific Research Publishing Inc.

This work is licensed under the Creative Commons Attribution International License (CC BY). http://creativecommons.org/licenses/by/4.0/

(c) (i) Open Access

\begin{abstract}
Two sublines of microalgae Dunaliella viridis Teodor. were obtained: CuS-a subline sensitive to toxic concentration of copper ions and $\mathrm{CuR}-\mathrm{a}$ subline resistant to toxic concentration of copper ions. The chronological aging of cultures was revealed in increase of DNA (polyploidization) and triacylglycerols (TAG) content in microalgae cells. The adaptation of $D$. viridis to toxic concentrations of copper ions resulted in formation of an adaptive epygenotype characterized by increased content of carbonylated proteins and decreased content of proline compared to the CuS-subline. The adaptation of $D$. viridis to toxic concentrations of copper ions resulted in the increase of the rate of chronological aging compared to the CuS-subline. Four subcultures with different rates of transplanting were obtained from each subline. The rate of replicative aging was shown to be dependent on the rate of chronological aging of subcultures (passage rate). The pre-adaptation of $D$. viridis to toxic concentrations of copper ions was accompanied by increase of accumulation rate of TAG and DNA in cells, which was interpreted as a sign of cellular aging during the progressive passages of the algae culture.
\end{abstract}

\section{Keywords}

Microalgae Dunaliella viridis, Adaptation to Copper Ions, Chronological and Replicative Aging, Epigenotype

\footnotetext{
${ }^{*}$ Corresponding author.
}

How to cite this paper: Bozhkov, A.I., et al. (2014) The Rate of Aging of the Dunaliella viridis Teodor. Culture Depends on the Algae Pre-Adaptation to Copper Sulfate Toxic Effect. Advances in Aging Research, 3, 187-198. 


\section{Introduction}

The principal proposition of modern gerontology is based on the assumption that increasing age decreases the organism's ability to effectively adapt to diverse environmental factors, leading to a breach in the system of metabolic regulation and is manifested in the development of age-related pathologies [1] [2].

All existing hypotheses in gerontology come to one extent or another to an attempt at accounting for this phenomenon. They can boil down to a few provisions: first, possible increase in production of free radicals accompanied by decrease of activity in enzymatic and non-enzymatic antioxidant systems in ontogeny [3]. Second, possible depletion of pool of stem and cambium cells accompanied by a loss of regenerative potential and increase in susceptibility of cell and tissue to damage [4] [5]. Third, various genetic and metabolic changes may result in violations in regulation, and upon reaching a certain critical level will take the form of age-related pathologies [6] [7]. And finally, in the process of ontogeny one can observe mechanical wear of a number of systems and loss in robustness of their functioning [8] [9].

In addition, there is enough evidence of preservation of a high regeneration and adaptive capacity in old organisms [10]-[12].

It has been shown that the ability to adapt not only decreases with age, but the adaptation strategy changes with age [13], i.e. the way the organism changes its way of "fighting" changes of negative environmental factors. It is of vital importance to understand what the change of adaptation strategies of aging organisms is based on and what role it plays in the formation of age-related pathologies and aging.

We have put forward a hypothesis that the selection of adaptation strategies is determined by the individual metabolic and epigenetic memory accumulated during the lifetime of the organism, in other words, its prehistory or genesis [11] [13] [14]. To put it in a simplified way, the more metabolic events that depend on the organism's prehistory are remembered, the narrower the range of potential metabolic "solutions" in response to changing environmental conditions is. The accumulation of metabolic memory is a result of a continuous process of adaptation, i.e. ontogeny is nothing more than a genesis of adaptations.

Consequently, ontogeny is not a count-down of astronomical time, but rather metabolic memory of previous adaptive processes (metabolic specialization). This study is aimed at verification of this statement. If two organisms or cell populations of the same age experienced various adaptive load, i.e. have a different prehistory, the aging rate or, to be more exact, the rates of age-related changes may be different in them. In the process of further adaptations these organisms will differ still more in the adaptive capabilities and the aging rate.

To test this hypothesis, we explored two sublines of Dunaliella viridis obtained by us. One of them was adapted to growing in an environment with a high content of copper ions, and the other one, remained susceptible to the toxic substance, i.e. they had a different prehistory.

Therefore, in this investigation the following problems were solved: 1 -determination of the pattern of several metabolic parameters-epigenotype providing the algae resistance to toxic concentrations of copper ions, 2evaluation of the relative rate of chronological aging of the two sublines of Dunaliella viridis, adapted and nonadapted to copper ions, 3-determination of the rate of replicative aging of four subcultures of two sublines of Dunaliella viridis.

\section{Materials and Methods}

\subsection{Culture Conditions}

The culture of one-cell microalgae Dunaliella viridis Teodor. var. viridis f. euchlora, strain IBASU-A N 29 was used in experiments (from the collection of microalgae cultures of M.G. Kholodny Institute of Botany, Kyiv, Ukraine).

The microalgae were cultivated on the liquid Artary medium, Massjuk modification [15] in Erlenmeyer's 250 ml-flasks (volume of the cultural medium was $20 \mathrm{ml}$, initial cell concentration-1.3 $\mathrm{mln} / \mathrm{ml}$ ) with twenty-fourhour illumination (4 klx), at constant temperature $26^{\circ} \mathrm{C}-28^{\circ} \mathrm{C}$.

To obtain different subcultures, the microalgae cells were transferred to fresh Artari medium:

- every 10 days, mid-exponential phase, subculture-10;

- every 20 days, attainment of stationary growth phase, subculture-20;

- every 30 and 40 days (early and late stationary phase, subculture-30 and -40, accordingly (Figure 1). Cells were counted in a Goriaev-chamber. Cell concentration was assessed in millions of cells per ml. 


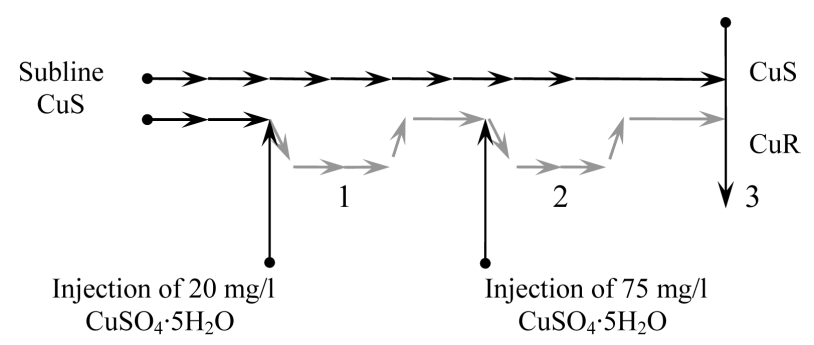

Figure 1. The scheme of obtaining of the CuR-subline during the stair-step adaptation to increasing copper content in culture medium from the initial CuS-subline of microalgae $D$. viridis. $1-$ the stage of active rearrangements in a series of successive passages on the medium from $20 \mathrm{mg} / \mathrm{CuSO}_{4} \cdot 5 \mathrm{H}_{2} \mathrm{O} ; 2$ - the stage of active rearrangements in a series of successive passages on the medium from $75 \mathrm{mg} / \mathrm{l} \mathrm{CuSO}_{4} \cdot 5 \mathrm{H}_{2} \mathrm{O}$; 3 - the characteristic of the $\mathrm{CuS}$ - and CuR-sublines when they were growing at the same rate, though having quite different prehistory of cultivation.

\subsection{Determination of Lipid Content in the Microalgae Cells}

The $D$. viridis cells were precipitated by centrifugation for $20 \mathrm{~min}$ at $3000 \times \mathrm{g}$ and were rinsed with Artary medium twice. Lipids were subsequently extracted with mixtures of organic solvents as previously described [16]. The chloroform extracts were analyzed by means of thin-layer chromatography on the plates Kieselgel 60 (Merck, Germany) using hexan (“Sangva Ltd.”, Ukraine): diethylated ether (4:1). The lipids content was assessed on calibration curves and was expressed in $\mu \mathrm{g}$ per a million of cells.

\subsection{Determination of Nucleic Acids and Protein Content}

DNA and RNA contents were determined by spectrophotometric methods by Spirin method [17]. RNA and DNA were hydrolyzed in the pellets after lipid extraction. After DNA and RNA hydrolysis, the pellets were dissolved in $1 \mathrm{~N} \mathrm{NaOH}$ ("Sangva Ltd.", Ukraine), and the protein content was determined with the help of Lowry method [18], the protein content was expressed in $\mu \mathrm{g}$ per a million of cells.

\subsection{Carbonylated Proteins Determination}

The content of carbonylated proteins was determined in pellets after extraction of lipids, pigments and hydrolysis of DNA and RNA. Carbonyl contents were measured with the help of the method described by Levine, with modifications [19]. The carbonyl content was calculated from the absorbance peak (355 - $390 \mathrm{~nm}$ ) using an absorption coefficient of 22,000 $\mathrm{mol} / \mathrm{l} \cdot \mathrm{cm}$ against pellets derived from the $2.5 \mathrm{~mol} / \mathrm{l} \mathrm{HCl}$ ("Chem-Synthesis", Ukraine)-treated samples. The quantity of carbonylated proteins was expressed by nmol per mg of protein.

\subsection{Determination of free Proline Content}

The proline content was determined by means of the Bates method [20]. The extinction of toluene phase was determined at $\lambda=520 \mathrm{~nm}$ using the spectrophotometer SF-46 (LOMO, Russia). The proline content was assessed on calibration curves and was expressed in $\mu \mathrm{g}$ per a million of cells.

\subsection{Determination of Copper Content}

The copper content of microalgae cells was determined by atomic adsorption spectrophotometry as previously described in [21].

\subsection{Statistical Processing}

The results were statistically processed and the significance of difference was assessed by Wilcoxon-MannWhitney test for small samples. 
Strange attractors of growth rate of microalgae were based on time-series final cell concentration of four different subcultures using card time delay with Mat Lab 6 software.

\section{Results}

\subsection{The Procedure of Obtaining Two D. viridis Sublines-Sensitive to Copper Ions (CuS) and Resistant to Copper Ions (CuR)}

Two sublines were obtained from the stock culture of $D$. viridis. One of the sublines was maintained in strictly standard for the culture conditions which have remained unchanged for 20 years at least. This is the $D$. viridis subline sensitive to high concentrations of copper ions-CuS-subline [16] [22].

To get the subline resistant to copper ions, $20 \mathrm{mg} / \mathrm{l}$ of $\mathrm{CuSO}_{4} \cdot 5 \mathrm{H}_{2} \mathrm{O}$ was added in the culture of $D$. viridis at each transfer every $21^{\text {st }}$ day. In this case, most of the cells died, and the remaining cells after 15 - 20 passages in medium with $20 \mathrm{mg} / \mathrm{l}$ of $\mathrm{CuSO}_{4} \cdot 5 \mathrm{H}_{2} \mathrm{O}$ restored their growth rate which is typical of the CuS-subline (Figure 1). The subline obtained during a long-term cultivation was named a subline resistant to copper ions-CuR-subline D. viridis (Figure 1).

The results on adding of a lethal dose of $\mathrm{CuSO}_{4} \cdot 5 \mathrm{H}_{2} \mathrm{O}(75 \mathrm{mg} / \mathrm{l})$ to the $D$. viridis culture suggest formation of resistance of the $D$. viridis CuR-subline to copper ions. If the adding of $75 \mathrm{mg} / \mathrm{l}$ of $\mathrm{CuSO}_{4} \cdot 5 \mathrm{H}_{2} \mathrm{O}$ leads to death of more than $99 \%$ of cells of the CuS-subline $D$. viridis, the same amount of copper in CuR-subline of $D$. viridis had no effect on the rate of its growth. Its growth rate does not differ from the growth rate of the standard CuSsubline (Figure 2).

Consequently, pre-adapted to copper ions (20 mg/l CuSO$\left.{ }_{4} \cdot 5 \mathrm{H}_{2} \mathrm{O}\right)$, D. viridis developed pronounced hormesis effect to lethal concentrations of copper. The CuS- and CuR-sublines of $D$. viridis did not differ in the growth rate, and they had different prehistory consisting of no less than 220 passages.

\subsection{Characteristics of Epigenotypes of $D$. viridis Cultures Resistant and Sensitive to High Concentrations of Copper}

The next step included comparison of some metabolic parameters (epigenotypes) in the CuS- and CuR-sublines of $D$. viridis.

It is known that copper ions are essential for algae development and in a standard culture their concentration is $0.3 \times 10^{-6} \mathrm{~mol} / \mathrm{l}$. At the same time, the CuR-subline of $D$. viridis successfully grown in a medium with $300 \times$ $10^{-6} \mathrm{~mol} / \mathrm{l}$ of copper, i.e. 1000 -fold higher concentration compared to the reference culture.

Determination of copper content in the cells of the CuS- and CuR-sublines of D. viridis at accumulating cultivation on the $10^{\text {th }}, 20^{\text {th }}, 30^{\text {th }}$ and $40^{\text {th }}$ day revealed:

1. The copper content in cells cultivated in the standard culture media $\left(\mathrm{Cu}^{2+}\right.$ was not additionally added) re-

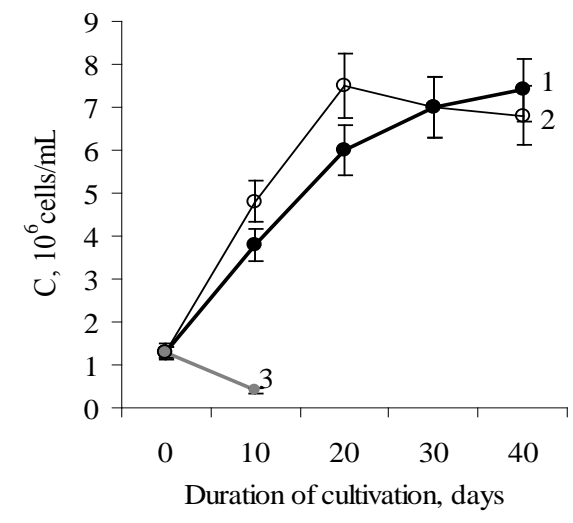

Figure 2. The dynamics of growth of microalgae D.viridis. 1 - the CuS-subline on standard Artari medium; 2-the CuRsubline on Artari medium with $75 \mathrm{mg} / \mathrm{l}$ of $\mathrm{CuSO}_{4} \cdot 5 \mathrm{H}_{2} \mathrm{O}$; 3 the CuS-subline on Artari medium after the first introduction of $75 \mathrm{mg} / \mathrm{CuSO}_{4} \cdot 5 \mathrm{H}_{2} \mathrm{O}$. 
duced $2.5-2.7$ times from the $10^{\text {th }}$ to the $40^{\text {th }}$ day of cultivation, (from $0.05 \times 10^{-9} \mathrm{~mol} / \mathrm{mln}$ cells to $0.018 \times$ $10^{-10} \mathrm{~mol} / \mathrm{mln}$ cells) (Figure 3(a));

2. The copper content in the cells of the CuR-subline on the $10^{\text {th }}$ day of cultivation after adding of $75 \mathrm{mg} / \mathrm{l}$ of $\mathrm{CuSO}_{4} \cdot 5 \mathrm{H}_{2} \mathrm{O}$ was 2000 times bigger than in cells of the CuS-subline;

3. The copper content in cells of the CuR-subline of $D$. viridis decreased during accumulative cultivation from the $10^{\text {th }}$ to the $40^{\text {th }}$ day of growth. However, the decrease rate was significantly (almost 2 times) higher in comparison with cells of the CuS-subline of $D$. viridis (Figure 3(b)).

It may be assumed that one of the elements of the adaptation mechanism of the CuR-subline to high concentrations of copper is excretion of copper into the culture medium.

Such high levels of copper in the cells of the CuR-subline of $D$. viridis definitely influences the pattern of metabolic parameters (epigenotypes). To estimate the metabolic characteristics of cells of the CuS- and CuRsublines, the content of carbonylated proteins, a product of free radical processes, was determined.

Carbonylated proteins were found at all stages of growth of the reference CuS-subline. Their content remained unchanged from the $10^{\text {th }}$ to the $30^{\text {th }}$ day of culture growth and was $1.1-1.4 \mathrm{nmol} / \mathrm{mg}$ of protein, and by the $40^{\text {th }}$ day had increased twice (Figure 4). The content of carbonylated proteins in cells of CuR-subline in

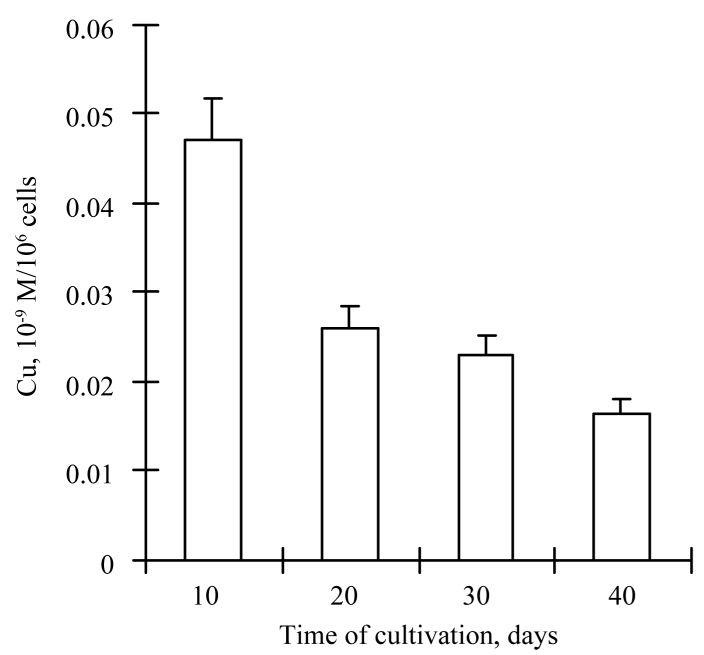

(a)

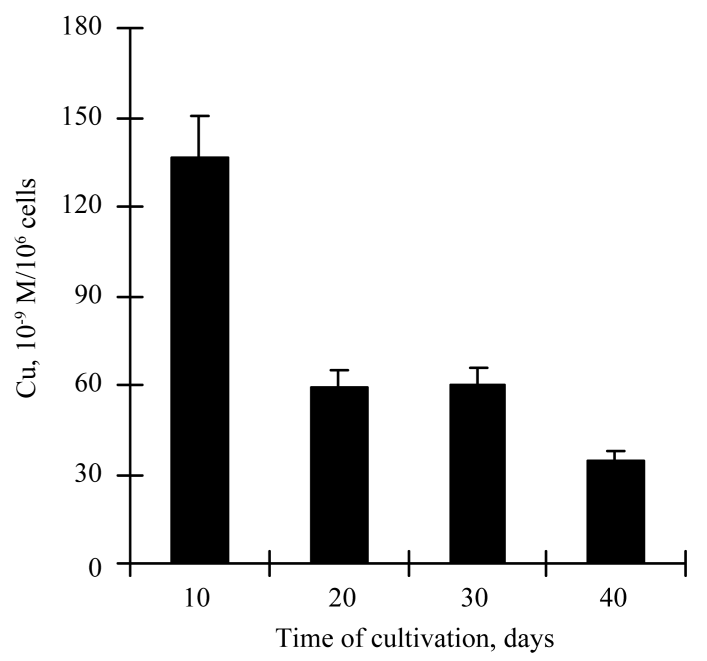

(b)

\section{Figure 3. The copper content ( $10^{-9} \mathrm{M} / 10^{6}$ cells) in cells of the CuS- (a) and CuR-sublines (b) of D. viridis.}

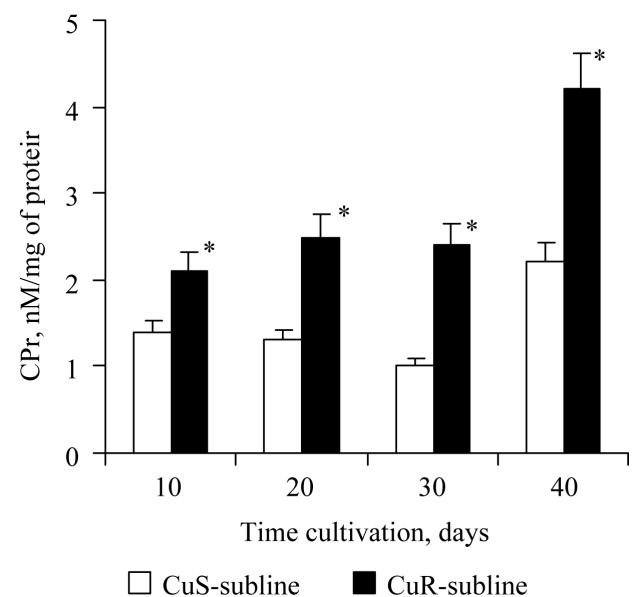

Figure 4. The content of carbonylated proteins ( $\mu \mathrm{g} / 10^{6}$ of cells) in cells of the CuS- and CuR-sublines of $D$. viridis. * significant differences of measures between the CuR-subline and CuS-subline. 
creased 2-fold compared to CuS-subline cells at all stages of growth. The character of temporal changes of this parameter was the same as for the CuS-subline (Figure 4).

Such saltatory increase of content of carbonylated proteins in cells of the 40 day-old cultures in both the CuSand CuR-sublines can be one of indicators of chronological aging of $D$. viridis cells. It should be noted that the 40-day-old culture is at a late stage of its stationary growth (Figure 2).

It is generally known that in plant cells free proline is a component of the antioxidant defense system [23].

The content of free proline in the cells of the CuS-subline of $D$. viridis was $0.072 \mu \mathrm{g} / 10^{6}$ of cells. It remained unchanged on the $20^{\text {th }}$ day of growth and increased 2-fold by the $30^{\text {th }}$ day and again decreased by the $40^{\text {th }}$ day (Figure 5). The content of free proline in the cells of the CuR-subline changed over time similarly to the culture of the CuS-subline, but at all stages of the growth its content was 2 times less than in cells of the CuS-subline (Figure 5). Consequently, we may observe a correlation between the decrease of free proline content and increase of content of carbonylated proteins.

The DNA content in D. viridis cells increases during chronological and replicative aging [16]. The amount of DNA in cells of the CuS-subline remained unchanged on the $10^{\text {th }}, 20^{\text {th }}$ and $30^{\text {th }}$ day of cultivation, and by the $40^{\text {th }}$ day it had increased 2-fold (Figure 6). The DNA content of the cells of the CuR-subline was insignificantly higher on the $10^{\text {th }}$ and $20^{\text {th }}$ day compared to the CuS-subline and had increased 3 times by the $30^{\text {th }}$ day and 1.8

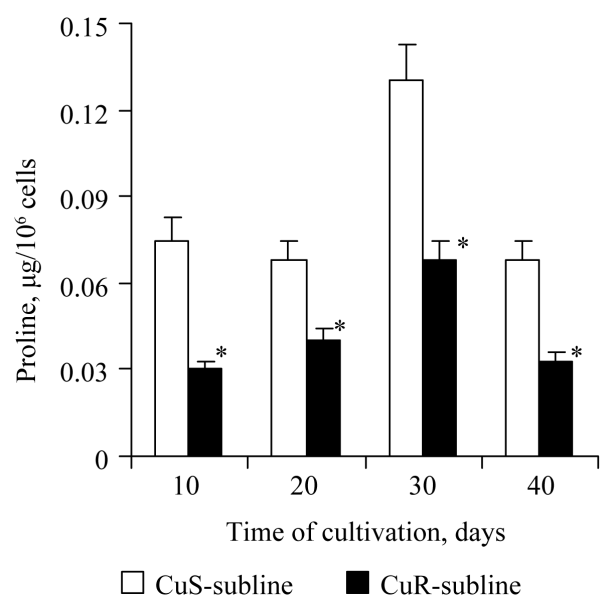

Figure 5. The proline content ( $\mu \mathrm{g} / 10^{6}$ of cells) in cells of the CuS- and CuR-sublines of $D$. viridis. ${ }^{*}$ significant differences of measures between the CuR-subline and CuS-subline.

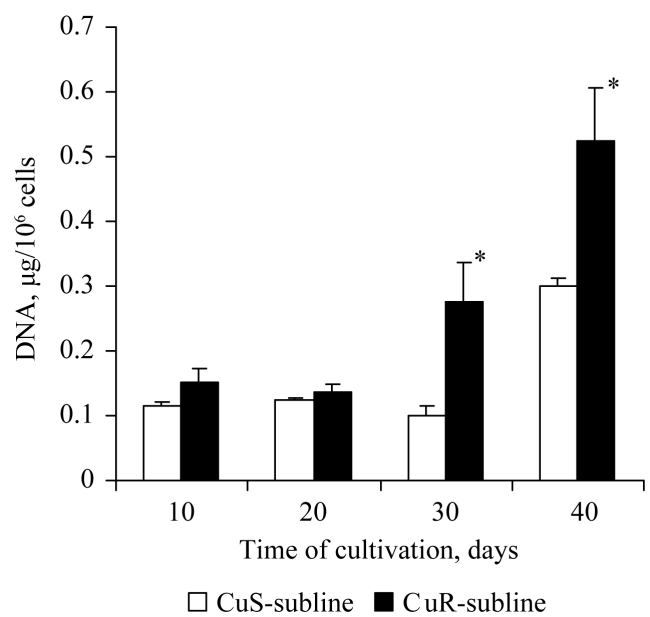

Figure 6. The content of DNA in cells of the CuS- and CuR-sublines of $D$. viridis at the $10^{\text {th }}$ passsage. ${ }^{*}$ significant differences of measures between the CuR-subline and CuS-subline. 
times by the $40^{\text {th }}$ day of cultivation (Figure 6). Consequently, the rate of DNA accumulation in the culture adapted to copper was significantly higher as compared to the CuS-subline.

The triacylglycerols (TAG) content in cells of the CuS-subline (as one of the indicators of aging) had increased by the $30^{\text {th }}$ and $40^{\text {th }}$ day compared to the $10^{\text {th }}$ day of culture growth 2.1 and 2.6 times (Figure 7). But the content of TAG in cells of the CuR-subline had increased by the $30^{\text {th }}$ and $40^{\text {th }}$ day compared to the $10^{\text {th }}$ day of growth 3.7 times and 2.6 times, respectively. The TAG content in the CuR-subline cells was higher at all stages of culture growth compared to the CuS-subline (Figure 7). Consequently, in this aspect chronological aging was more evident in the CuR-subline as compared to the CuS-subline.

The cells of the CuS- and CuR-sublines did not differ in the content of RNA, total protein, $\beta$-carotenes and in the growth rate.

The results obtained suggest that CuR-subline cells of D.viridis realized a different, distinct from the CuSsubline epigenotype - a pattern of metabolic indices which provided their adaptation to extreme conditions.

Thus we can conclude that:

1. The culture of $D$. viridis is able to adapt to high concentrations of copper in the medium (1000 times higher than the standard level). In our the content of copper in the cells exceeded the eference sample 2900 times experiments on $10^{\text {th }}$ day of growth;

2. The growth rate of the copper-adapted CuR-subline did not differ from CuS-subline which was cultured under standard conditions;

3. Maintaining of the intensity of growth of the CuR-subline on the level of the CuS-subline was provided by a large number of cooperative changes in metabolism indices, i.e. forming an epigenotype with the same RNA and protein content as in cells of the CuS-subline;

4. If we assume that increase in the DNA content (ploidy level of cells), the content of triacylglycerols and carbonylated proteins is an indicator of aging rate of $D$. viridis cultures, the CuR-subline is characterized by a high rate of chronological aging compared to the CuS-subline.

\subsection{Determination of the Rate of Replicative Aging of Two Sublines of $D$. viridis}

To estimate the rate of replicative aging of both CuR- and CuS-sublines, four subcultures were obtained from each line (Figure 8). The subcultures differed in the intensity of transfer at intervals of 10, 20, 30 and 40 days respectively. In this mode of cultivation the subcultures were maintained for 2 years.

It was found that regular transfer of subculture-10 of the CuS-subline to fresh medium for 2 years did not lead to any substantial changes in the DNA content of D. viridis cells (Figure 9(a)). With subculture-20 of the CuSsubline, we observed a slow but steady increase in the DNA content during long passages (Figure 9(a)). At the same time, the content of DNA in the cells of subculture-30 of the CuS-subline sharply increased more than 5 times from the $10^{\text {th }}$ to the $40^{\text {th }}$ passages (Figure $9(\mathrm{a})$ ).

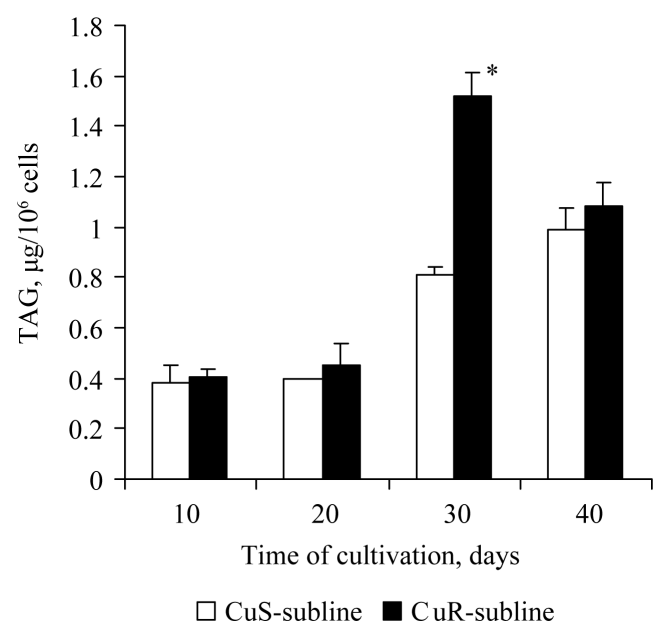

Figure 7. The content of TAG in cells of the CuS- and CuR-sublines of $D$. viridis at the $10^{\text {th }}$ passsage. * significant differences of measures between the CuR-subline and CuS-subline. 

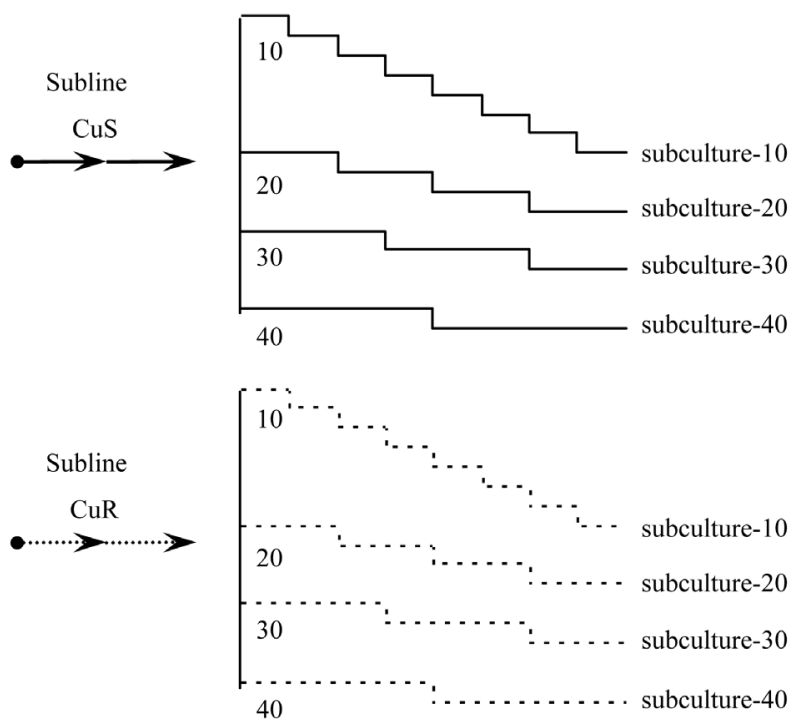

Intervals between passages, days

Figure 8. The scheme of obtaining of subcultures-10, -20, -30 and -40 from the CuS- and CuR-sublines of $D$. viridis.

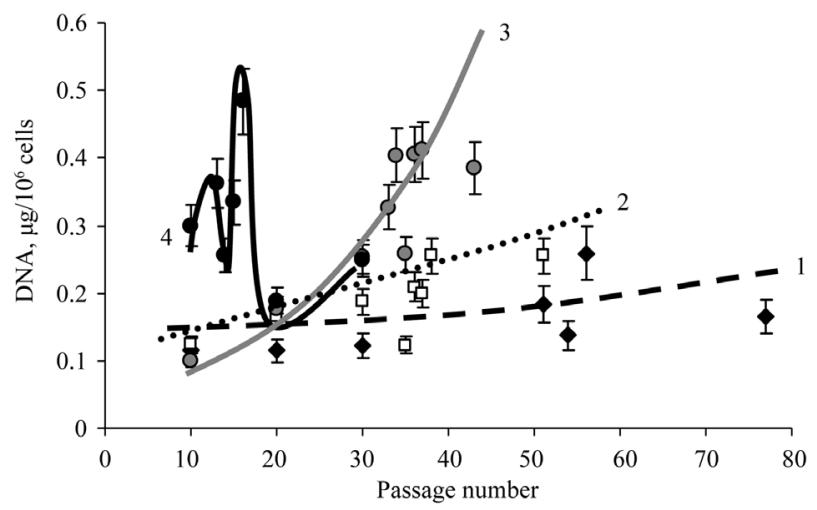

- Subculture-10 Subculture-20

(a)

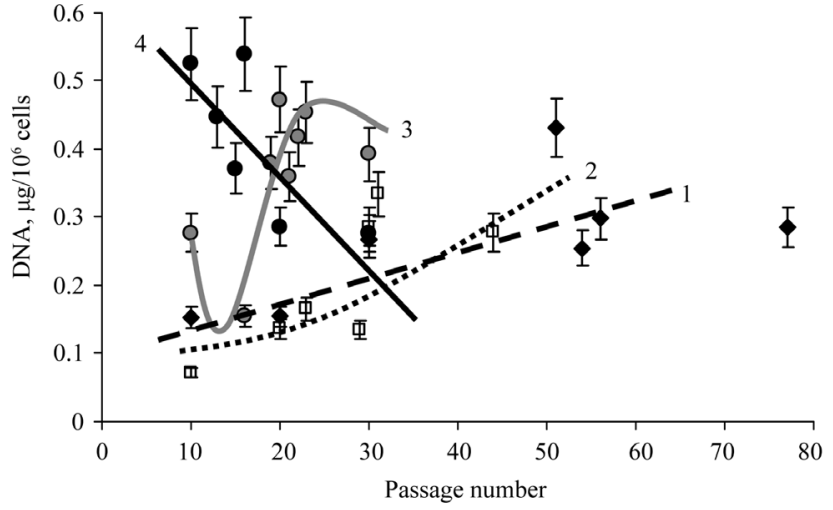

- Subculture-10 口 Subculture-20 O Subculture-30 • Subculture-40

(b)

Figure 9. The DNA content in cells of subcultures -10 (1), -20 (2),

-30 (3) and -40 (4) of the CuS-sublines (a) and CuR-sublines (b) of D. viridis at continuous cultivation. 
Completely different changes of the DNA content were observed during long-term passage of subculture-40 of the CuS-subline. Firstly, the DNA content in the cells of subculture-40 was 2 - 4 times higher than in the subcultures-10 and -20 of the CuS-sublines. Secondly, there were the sharp changes of DNA content in cells during long-term cultivation (Figure 9(a)). Consequently, the rate of replicative aging using DNA content as a criterion of aging depends on the rate of the transfer of the culture and is different for different subcultures.

The DNA content of the subcultures of CuR-subline of $D$. viridis changed not so as for subcultures of CuSsubline. If the rate of increase of DNA content in subculture-10 and subculture-20 of CuR-subline of $D$. viridis differed slightly, for the subculture-30 of CuR-subline DNA content was highly variable, as in the subculture-40 of CuS-subline (Figure 9(b)). At the same time, for subculture- 40 of CuR-subline of $D$. viridis an almost linear sharp decrease in DNA content from 10 to 30 passages was observed (Figure 9).

Consequently, the rate of replicative aging of subcultures of the CuR-subline, especially subcultures-30 and -40 , was significantly higher than that of the CuS-sublines of $D$. viridis.

The dynamics of the TAG content in the CuS- and CuR-sublines also suggests that replicative aging of subcultures occurs at a higher rate as compared to subcultures of the CuS-subline of $D$. viridis.

It was shown that the TAG content in cells of the CuS-subline in subculture-10 and in subculture-20 did not change significantly during long-term cultivation and was the lowest as compared to subculture-30 and 40 (Figure 10(a)).

A completely different dynamics of the TAG content was observed in subcultures of the CuR-subline of $D$. viridis (Figure 10). Thus, the content of TAG increased dramatically during continuous passaging of subculture10 and subculture-20 of the CuR-subline. For subculture- 30 of the CuR-subline, we observed marked variability
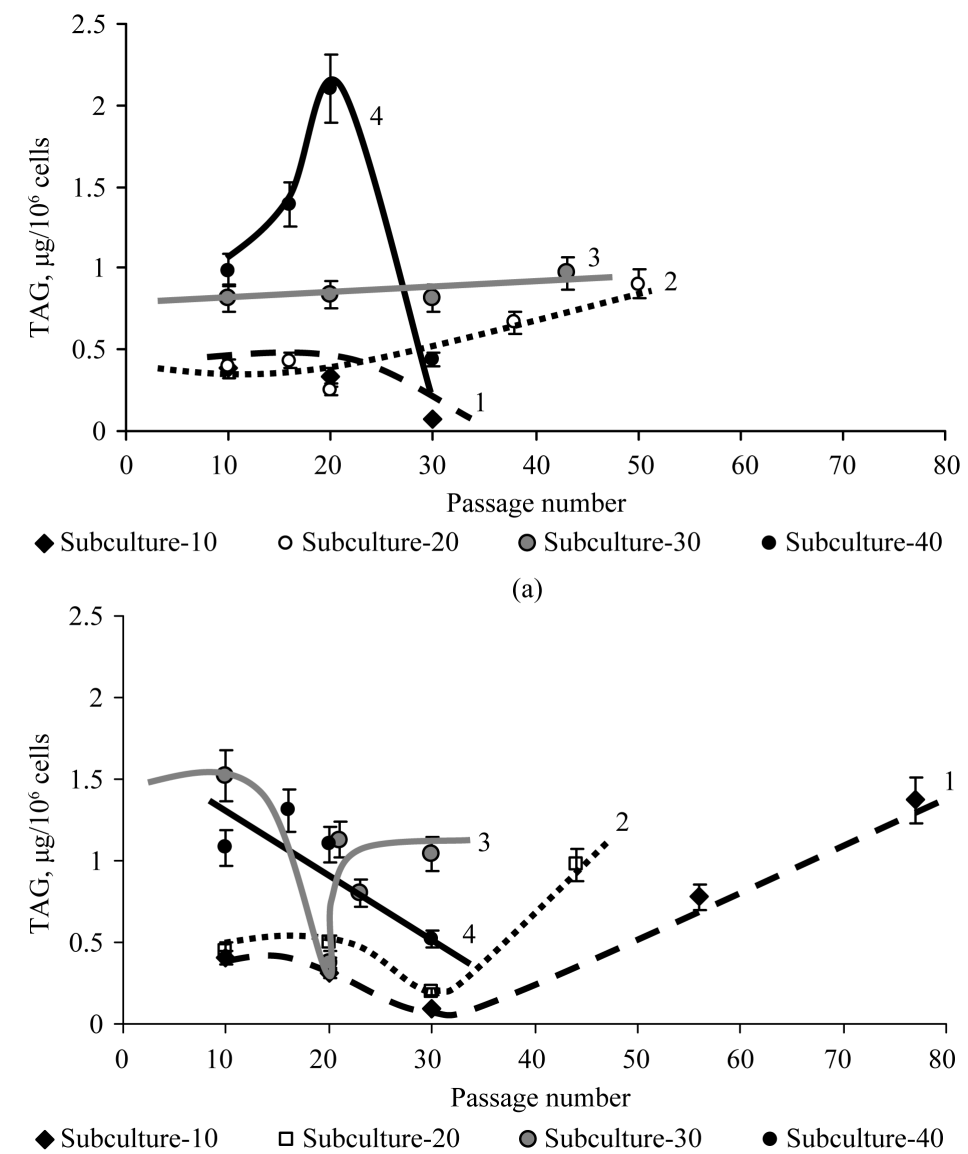

(b)

Figure 10. The content of TAG in cells of subculture-10 (1), -20 (2), -30 (3) and -40 (4) of the CuS-sublines (a) and CuR-sublines (b) of D. viridis at continuous cultivation. 
of this indicator, and for cells of subculture-40 we observed its decline (Figure 10(b)).

Consequently if from the point of view of the DNA and TAG content, subculture-10 of the CuS-subline of $D$. viridis does not "age" for 2 years of passaging and subculture-20 "ages" slowly, subculture-30 and especially subculture-40 "age" quickly during continuous passaging. The CuR-subline of $D$. viridis is characterized by more rapid replicative aging compared to the CuS-subline and this becomes evident even for subculture-10 of the CuR-subline.

\section{Discussion}

The results of this work are the following:

1. Culture $D$. viridis is able to adapt to growth in the medium with high concentrations of copper ions (lethal for the species), which enabled us to obtain two sublines with different prehistory;

2. The CuS- and CuR-sublines of $D$. viridis differed in patterns of metabolic parameters, i.e. had different epigenotypes;

3. Cell culture of the CuR- subline of $D$. viridis differed from the CuS-subline of $D$. viridis in an increased rate of chronological and replicative aging, i.e. prehistory formed as a result of adaption to toxic concentrations of copper ions affects the aging rate of cultures;

4. Subcultures-10, $-20,-30$ and -40 were characterized by different rates of replicative aging, i.e., chronological aging accelerates the rate of replicative aging of $D$. viridis.

These results can be accounted for on the basis of the hypothesis of the role of metabolic-epigenetic memory in aging [16].

Thus, the initial population of $D$. viridis is heterogeneous and is represented by cells different in their functional activity and age. After the first introduction of copper ions into the CuS-subline of $D$. viridis, most of the cells died, but a small number of cells retained their vitality [22]. The number of viable cells can be from a few to more than 10 percent, i.e. a selection cells takes place. One can assume that only the cells that originally had a specific epigenotype, i.e. a pattern of metabolic parameters capable of maintaining viability, survive.

The epigenotypes enabling cells to survive in the presence of high concentrations of copper ions have typical features: the ability to deposit copper in the cells and the capacity to excrete the copper rapidly. Such cells have an increased content of carbonylated protein (2 times); a 2-fold reduced content of free proline and many times increased content of DNA and TAG (Figure 4, Figure 6, Figure 7). Previously it was shown that such a specific epigenotype is characterized by increased activity of superoxide dismutase and probably by manifestation of emergent properties that provide not only cumulative effect of individual elements of resistance, but also new features [21]. As a consequence, such an epigenotype can be inducible to further strengthening and "consolidation" of the metabolic level memory.

At the initial stages of formation of specific epigenotypes, the cell population consists of relatively congenerous cells in relation to the structural and functional heterogeneity. At further stages the heterogeneity increases. It is suggested by the dynamics of strange attractors for subcultures of the CuS- and CuR-sublines (Figure 11).

This assumption leads to a conclusion that the "divergence" of metabolic characteristics is a fundamental property of biological systems, whereas the formation of specific epigenotypes adaptive to highly toxic factors to a certain extent constrains manifestation of such variability (Figure 11). We believe that this is manifested in induced metabolic memory. Such metabolic memory is designed to survive in extreme conditions and results in accelerated aging.

The greater rate of chronological and replicative aging of the CuR-subline can be accounted for by "fixation" or remembering of a specific epigenotype on the level of metabolic pattern, which greatly "reduces" possibility of upcoming adaptations. Since the "upcoming" epigenetic environmental factors are less harmful, i.e. not extreme and therefore do not promote salutatory selection like high concentrations of copper ions, they cannot "cancel" or "delete" metabolic-epigenetic memory already formed.

A formed adaptive epigenotype not only leads to accelerated aging, but may also, as a consequence, provide new properties for an organism. Thus, the CuR-subline of $D$. viridis was observed to exhibit enhanced heat resistance compared to the CuS-subline [21].

\section{Conclusion}

The adaptation of microalgae Dunaliella viridis to lethal concentrations of copper is accompanied by formation 

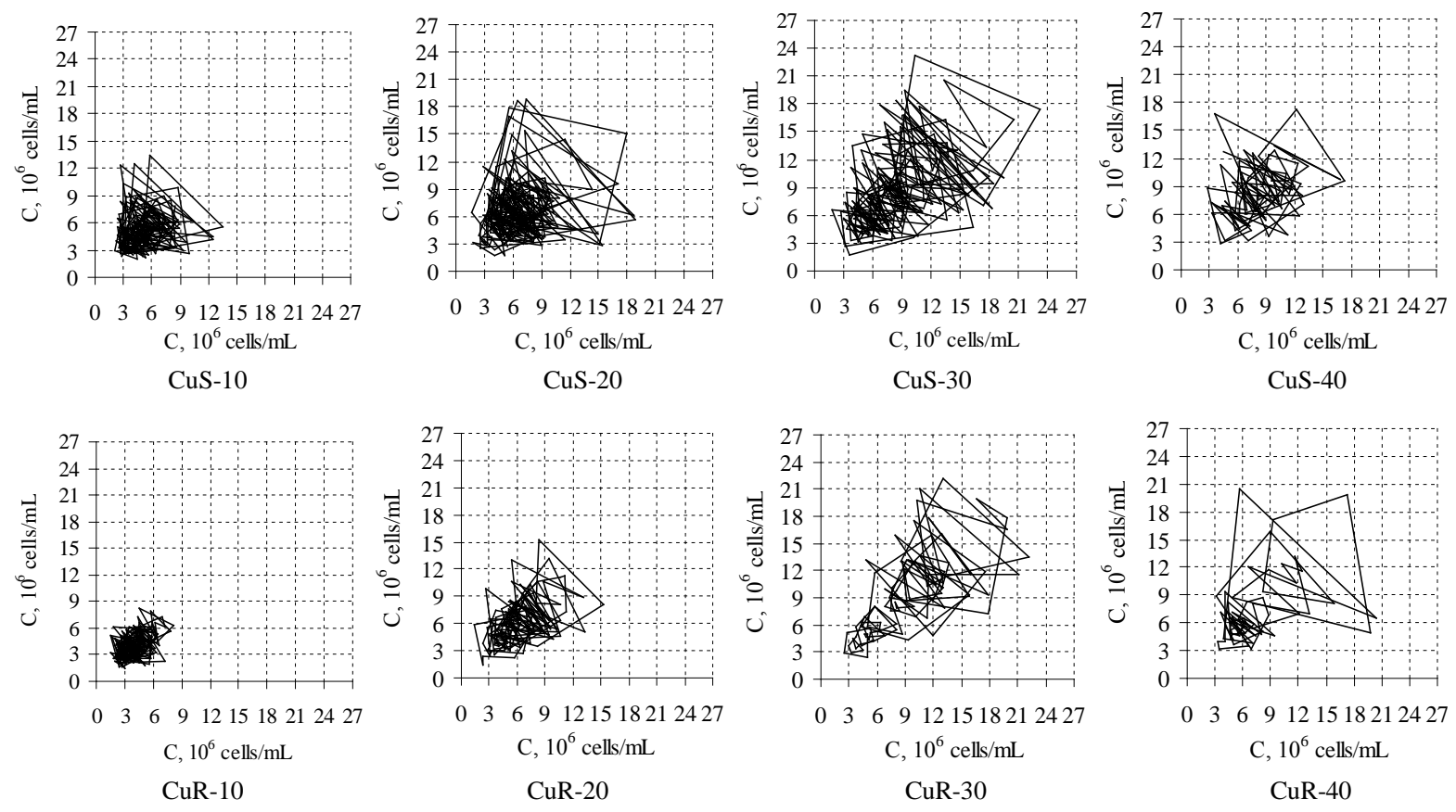

Figure 11. Strange attractors constructed with t he help of time delay method in the ranks of values of cell concentration for various subcultures of $D$. viridis on the $10^{\text {th }}, 20^{\text {th }}, 30^{\text {th }}$ and $40^{\text {th }}$ day of growth accordingly.

of a specific epigenotype. This epigenotype is characterized by acceleration of both chronological and replicative aging. The rate of replicative aging is significantly dependent on the rate of passaging. Subculture-10 transplanted on the stage of exponential growth was a chronologically "young” subculture and displayed no signs of replicative aging. Subcultures-30 and -40 with evident features of chronological aging were characterized by a high rate of replicative aging.

\section{References}

[1] Pérez, C., Navarro, A., Martínez, E., Ordóñez, C., Del Valle, E. and Tolivia, J. (2012) Age-Related Changes of Apolipoprotein D Expression in Female Rat Central Nervous System with Chronic Estradiol Treatment. Age (Dordr), 34, 895-904. http://dx.doi.org/10.1007/s11357-011-9286-5

[2] Ruan, Q.W., Yu, Z.W., Bao, Z.J. and Ma, Y.X. (2013) The Relationship between the Polymorphism of Immunity Genes and Both Aging and Age-Related Diseases. Yi Chuan, 35, 813-822. http://dx.doi.org/10.3724/SP.J.1005.2013.00813

[3] Wang, C.H., Wu, S.B., Wu, Y.T. and Wei, Y.H. (2013) Oxidative Stress Response Elicited by Mitochondrial Dysfunction: Implication in the Pathophysiology of Aging. Experimental Biology and Medicine (Maywood), 238, 450-460. http://dx.doi.org/10.1177/1535370213493069

[4] Kanawa, M., Igarashi, A., Ronald, V.S., Higashi, Y., Kurihara, H., Sugiyama, M., Saskianti, T., Pan, H. and Kato, Y. (2013) Age-Dependent Decrease in the Chondrogenic Potential of Human Bone Marrow Mesenchymal Stromal Cells Expanded with Fibroblast Growth Factor-2. Cytotherapy, S1465-S3249.

[5] Guang, L.G., Boskey, A.L. and Zhu, W. (2013) Age-Related CXC Chemokine Receptor-4-Deficiency Impairs Osteogenic Differentiation Potency of Mouse Bone Marrow Mesenchymal Stromal Stem Cells. The International Journal of Biochemistry \& Cell Biology, 45, 1813-1820. http://dx.doi.org/10.1016/j.biocel.2013.05.034

[6] Salvioli, S., Monti, D., Lanzarini, C., Conte, M., Pirazzini, C., et al. (2013) Immune System, Cell Senescence, Aging and Longevity-Inflamm-Aging Reappraised. Current Pharmaceutical Design, 19, 1675-1679.

[7] Domann, F.E. (2013) Aberrant Free Radical Biology Is a Unifying Theme in the Etiology and Pathogenesis of Major Human Diseases. International Journal of Molecular Sciences, 14, 8491-8495. http://dx.doi.org/10.3390/ijms14048491

[8] Koltover, V.K. (2009) Bioantioxidants: The Systems Reliability Standpoint. Toxicology and Industrial Health, 25, 295-299. http://dx.doi.org/10.1177/0748233709103029

[9] Koltover, V.K. (1997) Reliability Concept as a Trend in Biophysics of Aging. Journal of Theoretical Biology, 184, 
157-163. http://dx.doi.org/10.1006/jtbi.1996.0247

[10] Bozhkov, A.I. and Menzyanova, N.G. (2009) Calorie Restricted Diet Induces Alternative Pathways of Lipid Metabolism for Support of Proliferative Processes in Regenerating Liver. Advances in Gerontology, 22, 440-447.

[11] Bozhkov, A.I., Dlubovskaya, V.L., Dmitriev, Iu.V., Meshaikina, N.I., Maleev, V.A. and Klimova, E.M. (2011) Supposed Role of "Metabolic Memory" in Formation of Response Reaction to Stress-Factors in Young and Adult Organisms. Advances in Gerontology, 1, 63-71. http://dx.doi.org/10.1134/S2079057011010048

[12] Davydov, V.V., Dobaeva, N.M. and Bozhkov, A.I. (2004) Possible Role of Alteration of Aldehyde’s Scavenger Enzymes during Aging. Experimental Gerontology, 39, 11-16. http://dx.doi.org/10.1016/j.exger.2003.08.009

[13] Bozhkov, A.I., Dlubovskaya, V.L., Maleev, V.A., Dmitriev, Iu.V. and Beletskaya, L.B. (2006) The Growth Constraining Diet Causes Various Strategy of Adaptation in Young and Adult Animals. Advances in Gerontology, 19, 36-43.

[14] Bozhkov, A.I. (2001) A Low-Calories Diet as a Model of Life Span Expansion and Study of Mechanisms of Aging. Advances in Gerontology, 8, 89-99.

[15] Posudin, Yu.I., Massjuk, N.P. and Lilitskaya, G.G. (2004) Effect of Ultraviolet Radiation on Photomovement of Two Species of Dunaliella Teod. International Journal on Algae, 6, 61-73. http://dx.doi.org/10.1615/InterJAlgae.v6.i1.70

[16] Bozhkov, A.I., Kovaleva, M.K. and Menzyanova, N.G. (2011) Is it Possible to “Cancel” Aging Process of Cell Cultures under Optimal Conditions for Cultivation? Advances in Gerontology, 24, 26-37.

[17] Spirin, A.S. (1958) Spectrophotometric Determination of Total Nucleic Acids. Biokhimiya, 23, 656-662.

[18] Lowry, O.H., Rosebrough, N.J., Farr, A.L. and Randall, R.J. (1951) Protein Measurement with the Folin Phenol Reagent. Journal of Biological Chemisry, 193, 265-275.

[19] Levine, R.L., Garland, C.N., Oliver, C.N., et al. (1990) Determination of Carbonyl Content in Oxidatively Modified Proteins. Methods in Enzymology, 186, 464-478. http://dx.doi.org/10.1016/0076-6879(90)86141-H

[20] Bates, L.S., Waldren, R.P. and Teare, I.D. (1973) Rapid Determination of Free Proline for Water-Stress Studies. Plant and Soil, 39, 205-207. http://dx.doi.org/10.1007/BF00018060

[21] Kovaleva, M.K., Menzyanova, N.G., Jain, A., Yadav, A., Flora, S.J.S. and Bozhkov, A.I. (2012) Effect of Hormesis in Dunaliella viridis Teodor. (Chlorophyta) under the Influence of Copper Sulfate. International Journal on Algae, 14, 44-61. http://dx.doi.org/10.1615/InterJAlgae.v14.i1.40

[22] Bozhkov, A.I., Menzyanova, N.G., Sedova, K.V. and Goltvyanskiy, A.V. (2011) The Influence of High Temperature on Cells of Dunaliella viridis (Teod.) (Chlorophyta) Sensitive and Resistant to Copper Ions. International Journal on Algae, 13, 203-222. http://dx.doi.org/10.1615/InterJAlgae.v13.i3.10

[23] Rejeb, K.B., Abdelly, C. and Savouré, A. (2012) Proline, a Multifunctional Amino-Acid Involved in Plant Adaptation to Environmental Constraints. Biologie Aujourd'hui, 206, 291-299. http://dx.doi.org/10.1051/jbio/2012030

\section{Abbreviations}

TAG—triacylglycerols 